\title{
TINJAUAN IMPLEMENTASI PENGELOLAAN DANA DESA DIKECAMATAN SITINJAU LAUT BERDASARKAN PERATURAN BUPATI KERINCI NO 21 TAHUN 2019
}

\author{
PEBI JULIANTO
}

\author{
INSTITUT AGAMA ISLAM NEGERI KERINCI \\ email: \\ pebijulianto@gmail.com
}

\begin{abstract}
Review of the Implementation of Village Fund Management in Sitinjau Laut Subdistrict Based on the Kerinci Regent Regulation No 21 of 2019. The phenomenon that occurs in Sitinjau Laut Subdistrict has many problems, both in the areas of planning, implementation, administration, reporting, and village financial accountability. At the planning stage, the use of village funds tends to be more in the program to be implemented by the Village Head so that at the deliberation of the development plan, the impression of the community leaders present is only to listen and at the stage of discussing the plan to use village fund policies that are presented only certain people The results of the discussion of the work plan for the Use of Village Funds are not discussed in general so that the community does not even know that the village has received large funding assistance from the local government through the Regional Budget (APBD). village officials regarding village fund management policies. This study aims to determine how the priority of the use of village funds in Sitinjau Laut Subdistrict where village funds are used to finance government administration, development implementation, community development, and community empowerment. The research method used is qualitative, the data source in this study were 9 people. The data taken are primary data and secondary data.
\end{abstract}

Keywords: Planning, Implementation, Administration, Reporting, Accountability

\begin{abstract}
ABSTRAK
Tinjauan Implementasi Pengelolaan Dana Desa Di Kecamatan Sitinjau Laut Berdasarkan Peraturan Bupati Kerinci No 21 Tahun 2019. Fenomena yang terjadi di Kecamatan Sitinjau Laut terdapat banyak permasalahan, baik dibidang perencanaan, pelaksanaan, penatausahaan, pelaporan, dan pertanggungjawaban keuangan desa. Pada tahap perencanaan penggunaan dana desa lebih cenderung pada program yang akan dilaksanakan dibuat oleh Kepala Desa sehingga pada saat musyawarah rencana pembangunan, tokoh masyarakat yang hadir kesannya hanya sebatas untuk mendengarkan dan pada tahap pembahasan rencana penggunaan kebijakan dana desa yang dihadirkan hanya orangorang tertentu saja, hasil dari pembahasan rencana kerja Penggunaan Dana Desa tidak di musyawarahkan secara umum sehingga masyarakat bahkan tidak tahu bahwa desa mendapatkan bantuan dana yang besar dari pemerintah daerah melalui APBD (Anggaran Pendapatan Dan Belanja Daerah) oleh sebab itu masyarakat cenderung kurang berpartisipasi dalam kegiatan yang dilakukan oleh aparat desa mengenai kebijakan pengelolaan dana desa. Penelitian ini bertujuan untuk mengetahui Bagaimana prioritas penggunaan dana desa di Kecamatan Sitinjau Laut dimana dana desa digunakan untuk membiayai penyelenggaraan pemerintah, pelaksanaan pembangunan, pembinaan kemasyarakatan, dan pemberdayaan masyarakat. Metode penelitian yang digunakan adalah Kualitatif, Sumber data dalam penelitian ini adalah 9 orang. Data yang di ambil adalah Data Primer Dan Data Sekunder
\end{abstract}

Kata Kunci: Perencanaan, Pelaksanaan, penatausahaan, Pelaporan, Pertanggung jawaban 


\section{PENDAHULAN}

\section{Latar Belakang}

Berdasarkan Peraturan Bupati Kerinci Nomor 21 Tahun 2019 tentang Desa adalah untuk meningkatkan kinerja dan kualitas pelayanan penyelenggaraan pemerintah desa perlu memperhatikan kesejahteraan Kepala Desa, Sekretaris Desa, dan Perangkat Desa melalui penyesuaian penghasilan tetap Kepala Desa, Sekretaris Desa, dan Perangkat Desa.

Sejalan dengan hal tersebut sudah tentu pelaksanaan pendistribusian kewenangan, pembiayaan dan penataan system pengelolaan keuangan tidak dapat dilihat dari seberapa besar desa akan memperoleh tetapi hal tersebut harus diimbangi dengan sejauh mana instrument atau sistem pengelolaan keuangan desa saat ini mampu memberikan nuansa manajemen keuangan yang lebih adil, rasional, transparan, partisipatif dan bertanggungjawab. Secara khusus Peraturan Bupati Kerinci Nomor 21 Tahun 2019 Tentang Desa telah menetapkan landasan yang jelas dalam penataan pengelolaan dan pertanggungjawaban keuangan desa antara lain memberikan keleluasaan dalam menetapkan produk pengaturan yang berkenaan dengan desa.

Dalam sistem pemerintahan yang ada saat ini, desa mempunyai peran yang strategis dalam membantu pemerintah daerah dalam proses penyelenggaraan pemerintahan, termasuk pembangunan. Semua itu dilakukan sebagai langkah nyata pemerintah daerah mendukung pelaksanaan otonomi daerah di wilayahnya. Pengelolaan Dana Desa dimulai dari ketentuan dalam Peraturan Bupati Nomor 21 tahun 2019 tentang prioritas penggunaan Dana Desa, menyebutkan bahwa dana desa adalah dana yang bersumber dari anggaran pendapatan dan belanja negara yang diperuntukan bagi desa yang di transfer melalui anggaran pendapatan dan belanja daerah kabupaten dan digunakan untuk membiayai penyelenggaraan pemerintah, pelaksanaan pembangunan, pembinaan kemasyarakatan, dan pemberdayaan masyarakat dan dalam pasal (2) diterapkan pengaturan perioritas penggunaan dana desa bertujuan untuk memberikan acuan bagi desa yang menyelenggarakan kewenangan hak asal usul dan kewenangan lokal berskala desa yang dibiayai dari dana desa selama ini pembangunan desa hampir selalu dipilihkan dari atas, atau dikenal dengan istilah top down dan pelaksananya adalah dinas/instansi pemerintah melalui mekanisme proyek.

Meskipun pengusulannya dimulai dari desa, bahkan dusun, namun pada kenyataannya keputusan pilihan ada di tangan pemerintah daerah. Maka bukan tidak mungkin proyek yang datang ke desa bukanlah kebutuhan yang didambakan masyarakat, melainkan kebutuhan yang dirumuskan oleh pemerintah daerah. Biaya pembangunannya pun sudah bukan rahasia lagi, jauh lebih besar dari kebutuhan biaya dari kaca pandang masyarakat.

Dalam Peraturan Menteri Keuangan Republik Indonesia nomor 205 Tahun 2019 pasal 1 ayat (8) bahwa dana desa adalah dana yang bersumber dari anggaran pendapatan dan belanja negara yang diperuntukkan bagi desa yang ditransfer melalui anggaran pendapatan dan belanja daerah kabupaten/kota dan yang mana dana desa tersebut digunakan untuk membiayai penyelenggaraan pemerintahan, pelaksanaan pembangunan, pembinaan kemasyarakatan dan pemberdayaan masyarakat.

Berdasarkan penelitian awal atau fenomena yang ada pada informasi masyarakat menggambarkan bahwa:

1. Pengelolaan kebijakan Dana Desa di Kecamatan Sitinjau Laut masih terdapat banyak permasalahan, baik dibidang perencanaan, pelaksanaan, penatausahaan, pelaporan, dan pertanggungjawaban keuangan desa. 
2. Pada tahapan perencanaan penggunaan Dana Desa lebih cenderung pada program yang akan dilaksanakan dibuat oleh Kepala Desa sehingga pada saat musyawarah rencana pembangunan, tokoh masyarakat yang hadir kesannya hanya sebatas untuk mendengarkan.

3. Pada tahap pembahasan rencana penggunaan kebijakan Dana Desa yang dihadirkan hanya orang-orang tertentu saja.

4. Hasil dari pembahasan rencana penggunaan Dana Desa tidak di musyawarahkan secara umum sehingga masyarakat bahkan tidak tahu bahwa desa mendapatkan bantuan dana yang besar dari pemerintah daerah melalui APBD (anggaran pendapatan dan belanja daerah)

5. Oleh sebab itu masyarakat cenderung kurang berpartisipasi dalam kegiatan yang dilakukan oleh aparat desa mengenai kebijakan pengelolaan dana desa.

Aparatur desa sebagai penyelenggaraan pemerintahan desa hendaknya memperhatikan prioritas penggunaan dana desa sesuai dengan Peraturan Menteri Keuangan Republik Indonesia Nomor 205 tahun 2019 dimana dana desa digunakan untuk membiayai penyelenggaraan pemerintah, pelaksanaan pembangunan, pembinaan kemasyarakatan, dan pemberdayaan masyarakat, Hal ini dilakukan agar penggunaan dana desa dapat terarah dan hendaknya dapat bertujuan dalam peningkatan dan percepatan pembangunan desa dan juga masyarakat yang mempunyai kualitas sumber daya manusia yang tinggi.

Dengan demikian ini perlu dibuktikan secara formal melalui laporan realisasi penggunaan dana desa dan mengetahui pengakuan dari pihak terkait yang terlibat seperti aparat desa, tokoh agama, tokoh masyarakat dan warga sekitar pembangunan dalam penggunaan dana desa selama tahun 2019 yang telah berjalan, selanjutnya dilakukan observasi dan analisis mendalam terkait realisasi penggunaan dana desa, dampak yang timbul dan mengetahui faktor pendukung maupun penghambat implementasi kebijakan tersebut.

\section{Tinjauan Pustaka \\ Pengelolaan Dana Desa}

Menurut kementrian keuangan menerbitkan Peraturan Menteri Keuangan 205/PMK.07/2019 tentang pengelolaan dana desa.Dana Desa adalah dana APBN (anggaran pendapatan dan belanja negara) bagi desa, ditransfer melalui APBD (anggaran pendapatan dan belanja daerah) Kabupaten/kota.Dana desa digunakan untuk membiayai penyelenggaraan pemerintahan, pelaksanaan pembangunan, pembinaan kemasyarakatan dan pemberdayaan masyarakat.

Undang-undang nomor 6 tahun 2014 tentang desa dan peraturan menteri dalam negeri nomor 113 tahun 2014 tentang pengelolaan keuangan desa,di mana disebutkan bahwa pengelolaan keuangan desa adalah serangkaian kegiatan yang meliputi perencanaan, pelaksanaan, penatausahaan, pelaporan dan pertanggung jawaban.

Menurut Peraturan Bupati nomor 21 tahun 2019 penggunaan dana desa diprioritaskan untuk membiayai pelaksanaan program dan kegiatan dibidang pembangunan desa dan pemberdayaan masyarakat desa,membiayai pelaksanaan program dan kegiatan prioritas yang bersifat lintas bidang dan diharapkan dapat memberi manfaat sebesar-besarnya bagi masyarakat desa berupa peningkatan kualitas hidup,peningkatan kesejahteraan dan penanggulangan kemiskinan serta peningkatan pelayanan publik di tingkat desa.

\section{Tujuan Dan Prinsip Penggunaan Dana Desa}

Dalam peraturan Bupati Kerinci No 21 tahun 2019 BAB II pasal 2 dan pasal 3 terdapat tujuan dan prinsip penggunaan dana desa ialah Pengaturan prioritas penggunaan dana desa bertujuan untuk memberikan acuan bagi desa dalam menyelenggarakan kewenangan hak asal usul dan kewenangan lokal berskala desa yang dibiayai dari dana desa. 
Prioritas pengguna desa didasarkan pada prinsip-prinsip:

1. Keadilan : mengutamakan hak dan kepentingan seluruh warga desa tanpa membedabedakan

2. Kebutuhan prioritas : mendahulukan kepentingan desa yang lebih mendesak, lebih dibutuhkan dan berhubungan langsung dengan kepentingan sebagian besar masyarakat desa.

3. Terfokus : mengutamakan pilihan penggunaan dana desa pada 3 sampai dengan 5 jenis kegiatan sesuai dengan kebutuhan sesuai prioritas nasional, provinsi, kabupaten dan desa, dan tidak dilakukan praktik penggunaan dana desa yang dibagi rata.

4. Kewenangan desa : mengutamakan kewenangan hak asal usul dan kewenangan lokal berskala desa

5. Parsitipatif : mengutamakan prakarsa, kreativitas dan peran serta masyarakat desa.

6. Swakelola : mengutamakan kemandirian desa dalam pelaksanaan kegiatan pembangunan desa yang dibiayai dana desa

7. Berdikari : mengutamakan pemanfaatan dana desa dengan mendaya gunakan sumber daya desa untuk membiayai kegiatan pembangunan yang dikelola dari, oleh dan untuk masyarakat desa sehingga dana desa berputar secara berkelanjutan di wilayah desa dan/ atau kabupaten/ kota.

8. Berbasis sumber daya desa : mengutamakan pembedayaan sumberdaya manusia dan sumberdaya alam yang ada di desa dalam pelaksanaan pembangunan yang dibiayai dana desa.

9. Tipologi desa : mempertimbangkan keadaan dan kenyataan karakteristik geografis, sosiologis, antropologis, ekonomi, dan ekologi desa yang khas, serta perubahan atau perkembangan dan kemajuan desa.

\section{Prioritas Penggunaan Dana Desa}

Peraturan Bupati Kerinci No 21 tahun 2019 BAB III Pasal 4 menjelaskan beberapa prioritas penggunaan Dana Desa sebagai berikut :

a. penggunaan dana desa diprioritaskan untuk membiayai pelaksanaan program dan kegiatan dibidang pembangunan desa dan pemberdayaan masyarakat desa.

b. prioritas penggunaan dana desa sebagaimana dimaksud pada ayat (1) dapat digunakan untuk membiayai pelaksanaan program dan kegiatan prioritas yang bersifat lintas bidang.

c. prioritas penggunaan dana desa sebagaimana dimaksud pada ayat (1) dan ayat (2), diharapkan dapat memberikan manfaat sebesar-besarnya bagi masyarakat desa berupa peningkatan kualitas hidup, peningkatan kesejahteraan dan penanggulangan kemiskinan serta peningkatan pelayanan publik di tingkat desa.

d. Desa adalah desa dan desa adat yang disebut dengan nama lain, selanjutnya disebut desa, adalah kesatuan masyarakat hukum yang memiliki batas wilayah yang berwenang untuk mengatur dan mengurus urusan pemerintah, kepentingan masyarakat setempat berdasarkan prakarsa masyarakat, hak asal usul, dan/atau hak tradisional yang diakui dan dihormati dalam distem pemerintahan negara kesatuan republik indonesia. Peraturan Menteri Keuangan 205/PMK.07/2019 pasal 1 BAB 1. Dalam peraturan menteri keuangan 205/PMK.07/2019 pasal 2 BAB 1 ini dilampirkan pengelolaan dana desa yang meliputi:

1) Pengangaran

2) Pengalokasian

3) Penyaluran

4) penatausahaan, pertanggungjawaban, dan pelaporan pendoman penggunaan dan

5) pemantauan serta evaluasi 


\section{METODE PENELITIAN}

\section{Metode Penelitian \\ Pendekatan Penelitian}

Adapun bentuk penelitian yang digunakan adalah metode penelitian deskriptif kualitatif. Menurut Sugiyono (2013:15) menyatakan bahwa metode penelitian kualitatif adalah metode penelitian yang berdasarkan pada filsafat postpositivisme, digunakan untuk meneliti pada kondisi obyek yang ilamiah, (sebagai lawannya adalah eksperimen) dimana peneliti sebagai instrumen kunci.

\section{Informan Penelitian}

Teknik penentuan informan yang dilakukan oleh peneliti dalam penelitian ini adalah teknik purposive sampling. Menurut Sugiyono,"teknik purposive sampling adalah teknik pengambilan sampel sumber data dengan pertimbangan tertentu"(Sugiyono,2010:300).

Informan (narasumber) penelitian adalah seseorang yang memiliki informasi mengenai objek penelitian tersebut. Informan dalam penelitian ini yaitu berasal dari wawancara langsung yang disebut sebagai narasumber. Dalam penelitian ini menentukan informan dengan menggunakan teknik purposive,yaitu dipilih dengan pertimbangan dan tujuan tertentu, yang benar-benar menguasai suatu objek yang peneliti teliti.

Purposive sampling adalah teknik pengambilan sampel sumber data dengan pertimbangan tertentu. Pertimbangan tertentu ini, misalnya orang tersebut yang dianggap paling tahu tentang apa yang kita harapkan, atau mungkin dia sebagai penguasa sehingga memudahkan peneliti menjelajahi objek/situasi sosial yang diteliti. (Sugiyono,2012:54)

\section{Metode Penarikan Informan.}

Metode penarikan informan adalah teknik pengambilan sampel untuk menentukan sampel yang akan digunakan dalam penelitian (Sugiyono,2003:91). Dalam penelitian kualitatif proses sampling yang terpenting adalah bagaimana menentukan informan kunci atau situasi sosial tertentu yang sarat informasi sesuai dengan fokus penelitian (Bungi,2003:53). Purposive sampling adalah teknik pengambilan sampel sumber data dengan pertimbangan tertentu. (Sugiyono,2012:54).

Dalam penelitian ini peneliti menggunakan metode purposive sampling ,dengan menyertakan informan kunci (key informan) yang ditetapkan oleh peneliti yaitu Kepala Desa Simpang Belui, Kepala Desa Semumu, Kepala Desa Ladeh. Informan kunci adalah informan yang mengetahui secara mendalam permasalah yang sedang diteliti sedangkan informan biasa adalah informan yang ditentukan dengan dasar pertimbangan mengetahui dan berhubungan dengan permasalahan.

Dalam menentukan informan yang akan dipakai dalam suatu penelitian, spardley mengusulkan lima kriteria untuk pemilihan informan yaitu:

1. subjek yang telah cukup lama intensif menyatu dengan kegiatan atau aktifitas yang menjadi informasi

1. subjek yang masih terlibat secara penuh/aktif pada lingkungan atau kegiatan yang menjadi perhatian peneliti

2. subjek yang mempunyai cukup banyak waktu atau kesempatan untuk diwawancarai 
3. subjek yang dalam memberikan informasi tidak cenderung diolah atau dipersiapkan terlebih dahulu.

4. subjek sebelumnya tergolong masih "asing" dengan penelitian, sehingga peneliti merasa tertantang untuk belajar sebanyak mungkin dari subjek yang berfungsi sebagai "guru baru'bagi peneliti.

Mengacu pada pendapat ahli di atas dalam penelitian ini penulis mengambil informan dengan kriteria yaitu : Aparatur desa dan masyarakat yang terlibat dengan perencanaan pembangunan di Desa Simpang Belui, Desa Ladeh, Desa Semumu Kabupaten Kerinci.

\section{Metode Pengumpulan Data.}

Dalam penelitian ini digunakan dua sumber data, yaitu sumber data primer dan data sekunder :

\section{Sumber Data Primer}

Data primer dalam penelitian ini diperoleh dari lapangan atau lokasi yaitu di di Kecamatan Sitinjau Laut Berdasarkan Peraturan Bupati Kerinci Nomor 21 Tahun 2019. melalui kuesioner dan interview yang diberikan secara langsung kepada responden. Dalam penelitian ini kuesioner dan inteview dilakukan untuk memudahkan dalam mendefinisikan suatu data yang kemudian diolah dalam melakukan analisis data.

\section{Sumber Data Sekunder}

Data sekunder digunakan dalam penelitian ini diperoleh melalui berbagai data dari catatan-catatan, dokumentsi, laporan, artikel artikel dari internet serta berbagai refeensi mengenai Berdasarkan Peraturan Bupati Kerinci Nomor 21 tahun 2019.

\section{Teknik Pengumpulan Data}

Untuk memperoleh datayang diperlukan dalam penelitian digunakan teknik berikut:

\section{Wawancara}

Wawancara merupakan salah satu bentuk teknik pengumpulan data yang banyak digunakan dalam penelitian deskriptif kualitatif. Dalam penelitian ini, wawancara dilakukan dengan cara wawancara langsung baik secara struktur maupun bebas dengan pimpinan dan aparatur desa serta masyarakat tentang Pengelolaan Dana Desa di Kecamatan Sitinjau Laut Berdasarkan Peraturan Bupati Nomor 21 Tahun 2019.

\section{Dokumentasi}

Dokumentasi yaitu teknik pengumpulan data yang tidak langsung ditujukan pada subjek penelitian, namun melalui dokumen. Studi dokumentasi merupakan pelengkap dari penggunaan metode observasi dan wawancara dalam penelitian kualitatif. Pengumpulan data yang dilakukan dengan teknik pengumpulan data yang didukung dari data skunder yang berkitan dengan pengelolaan dana desa di kecamatan Sitinjau Laut berdasarkan Peraturan Bupati N omor 21 tahun 2019.

\section{Alat Pengumpulan Data Recorder/Handphone}

Alat yang digunakan untuk sebagai alat bantu pengumpulan infromasi dari informan dengan hasil rekaman suara dari informan wawancara. 


\title{
Kamera
}

Alat yang digunakan untuk mendokumentasikan pelaksanaan wawancara dengan informan sebagai dokumentasi dari kegiatan penelitian.

\begin{abstract}
Alat Tulis
Alat yang digunakan untuk mencatat dan mendijurnalkan hasil wawancara dari informan guna memudahkan peneliti untuk menyimpan data penelitian.

\section{Teknik pengolahan data}

Penelitian kualitatif dalam peroses penentuan sampel lebih tepat menggunakan sistem non probability sampling, karena dalam penelitian ini menggunakan salah satu teknik non probability sampling yaitu purposive sampling. Purposive sampling adalah teknik pengambilan sampel sumber data dengan pertimbangan atau tujuan tertentu. Pertimbangan atau tujuan tertentu ini misalnya orang atau responden tersebut dianggap tahu atau mewakili tentang apa yang akan di ungkapkan dalam penelitian.
\end{abstract}

\section{Teknik Analisa Data}

Analisa data merupakan proses mencari dan menyusun sistem secara sistematis data yang diperoleh dari hasil wawancara, kuesioner, catatan lapangan, dan dokumentsi dengan cara mengorganisasikan data ke dalam kategori, menjabarkan ke dalam unit-unit, melakukan sintesa, dan menyusun ke dalam pola, memilih mana yang penting dan yang akan dipelajari, dan membuat kesimpulan sehingga mudah dipahami oleh diri sendiri maupun orang lain.

Guna menganalisis data yang penulis kumpulkan maka digunakan metode analisis data yang bertitik tolak dari hal-hal yang khusus kemudian ditarik kesimpulan secara umum. Dalam penelitian ini peneliti menggunakan teknik analisa data yang bersifat deskriptifkualitatif, yaitu mendejurnalkan data yang diperoleh melalui instrumen penelitian. Analisis data adalah proses menyusun data agar dapat ditafsirkan. Analisis data ini sendiri dilakukan dalam tiga cara yaitu:

\section{Reduksi data}

Reduksi data merupakan proes pembinan, pemusatan, perhatian, pengabstraksian dan pentrsnformasian data kasar dari lapangan. Mereduksi data berarti merangkum, memilih halhal yang fokus, penting dalam penelitian, dengan demikian data yang telah diredusi akan memberikan gambaran yang lebih jelas dan mempermudah peneliti pengumpulan data selanjutnya.

\section{Display data}

Penyajian data adalah sekumpulan informasi yang dihasilkan dari observasi, wawancara, kuesioner dan dokumentasi dikumpulkan sehingga tersusun yang memberikan kemungkinan untuk menarik kesimpulan dan pengambilan tindakan, yang disajikan antara lain dalam bentuk teks naratif, matriks, jaringan Data yang direduksi selanjutnya dipaparkan. Pemaparan dilakukan sesuai hasil analisa (pengamatan) yang telah dilakukan. Teknik ini merupakan langkah ke dua setelah reduksi data guna memudahkan peneliti untuk memahami tentang permasalahan yang ada pada Pengelolaan Dana Desa Berdasarkan Peraturan Bupati Kerinci No 21 Tahun 2019. Dengan teknik ini, diharapkan penulis dapat memperoleh gambaran tentang Pengelolaan Dana Desa di Kecamatan Sitinjau Laut Berdasarkan Peraturan Bupati Kerinci Nomor 21 Tahun 2019. 


\section{HASIL DAN PEMBAHASAN}

\section{Pengelolaan Dana Desa}

Pengelolaan dana desa merupakan bagian dari pengelolaan keuangan desa yang meliputi perencanaan, pelaksanaan, penatausahaan, pelaporan, dan pertanggung jawaban. Semua proses ini dijalankan pleh pemerintah desa didampingi oleh Tim pendamping dari pemerintah, serta partisipasi masyarakat dalam pengawasan Dana Desa. Pengelolaan Dana Desa di Kecamatan Sitinjau Laut memiliki pedoman atau aturan seperti Peraturan Bupati Kerinci Nomor 21 Tahun 2019.

\section{Hasil Penelitian \\ Perencanaan}

Perencanaan merupakan proses atau rangkaian berupa kegiatan yang saling berhubungan dalam memilih salah satu di antara beberapa alternatif tentang tujuan yang ingin dicapai oleh sebuah organisasi/perusahaan. Kemudian memilih strategi dan metode untuk mencapai tujuan tersebut. Dilanjutkan pula dengan menetapkan anggaran untuk melaksanakan strategi dan metode tersebut, diiringi dengan memilih dan menetapkan kriteria tolak ukur untuk menilai tingkat keberhasilan organisasi/perusahaan dalam pencapaian tujuannya dengan mengimplementasikan strategi dan metode yang telah dipilih sebelumnya.

pemerintahan yang ada di Kecamatan Sitinjau Laut telah melakukan perencanaan pengelolaan Dana Desa dengan sebagaimana mestinya. Dengan telah dilakukan musyawarah untuk mencapai mufakat dengan tujuan untuk menyamakan persepsi dalam bekerja untuk mencapai satu tujuan dengan ketentuan-ketentuan yang berlaku.

Hal ini sesuai dengan pendapat Rustiadi (2008:339) perencanaan merupakan suatu proses menentukan apa yang ingin dicapai di masa yang akan datang serta menetapkan tahapantahapan yang dibutuhkan untuk mencapainya.

\section{Pelaksanaan}

Pelaksanaan dalam pengelolaan keuangan desa merupakan implementasi atau eksekusi dari Anggaran Pendapatan dan Belanja Desa. Termasuk dalam pelaksanaan diantaranya adalah proses pengadaan barang dan jasa serta proses pembayaran.

pelaksanaan pengelolaan Dana Desa di Kecamatan Sitinjau Laut telah berjalan dengan baik, terlihat pada setiap pelaksanaan pemerintahan selalu transparan kepada masyarakat dengan tujuan yang tercapai dengan ketentuan-ketentuan yang berlaku.

Hal ini sesuai dengan pendapat G.R Terry (2018:68) Pelaksanaan merupakan, kegiatan meliputi menentukan, mengelompokan, mencapai tujuan, penugasan orang-orang dengan memperhatikan lingkungan fisik, sesuai dengan kewenangan yang dilimpahkankan terhadap setiap individu untuk melaksanakan kegiatan tersebut.

\section{Penatausahaan}

Penatausahaan merupakan, kegiatan yang dilakukan secara sistematis (teratur dan masuk akal/logis) dalam bidang keuangan bedasarkan prinsip, standar, serta prosedur tertentu sehingga informasi aktual (informasi yang sesungguhnya) berkenaan dengan keuangan dapat 
segera diperoleh. Tahap ini merupakan proses pencatatan seluruh transaksi keuangan yang terjadi dalam satu tahun anggaran. Lebih lanjut, kegiatan penatausahaan keuangan mempunyai fungsi pengendalian terhadap pelaksanaan APBDesa. Hasil dari penatausahaan adalah laporan yang dapat digunakan untuk pertanggungjawaban pengelolaan keuangan itu sendiri.

penatausahaan pengelolaan dana desa di Kecamatan Sitinjau Laut telah dilakukan dengan cukup baik. Pemerintah desa memprioritaskan pembangunan dasar kebutuhan masyarakat, hal ini agar dapat mempermudahkan aktivitas masyarakat dan bemanfaat bagi seluruh masyarakat Kecamatan Sitinjau Laut itu sendiri dan sesuai dengan ketentuanketentuan tertentu.

\section{Pelaporan}

Pelaporan adalah suatu kegiatan yang dilakukan bawahan untuk menyampaikan hal-hal yang berhubungan dengan hasil pekerjaan yang telah dilakukan selama satu periode tertentu sebagai bentuk pelaksanaan pertanggungjawaban atas tugas dan wewenang yang diberikan.

laporan atas kegiatan-kegiatan dalam pembangunan pengelolaan dana desa telah dilaksanakan sesuai peraturan yang berlaku dan dimana sistim pelaporan pengelolaan dana desa telah dilakukan dengan tepat waktu dan dilakukan secara bersama-sama oleh kepala desa yang ada di Kecamatan Depati VII.

\section{PertanggungJawaban}

Pertanggungjawaban adalah suatu sistem akuntansi yang disusun sedemikian rupa sehingga pengumpulan dan pelaporan biaya dan pendapatan dilakukan sesuai dengan pusat pertanggungjawaban dalam organisasi dengan tujuan agar dapat ditunjukkan orang atau kelompok orang yang bertanggung jawab atas penyimpangan biaya dan pendapatan yang di anggarkan.

setiap pelaporan pertanggung jawaban pelaksanaan pengelolaan dana desa di Kecamatan Sitinjau Laut telah menyampaikan hasil pelaporan pertanggungjawaban dengan baik dan dapat menginformasikan kepada masyarakat secara tertulis dan maupun media informasi yang mudah di akses oleh masyarakat dan tentunya laporan pertanggungjawaban tersebut telah sesuai dengan aturan dan ketentuan-ketentuan tertentu.

\section{SIMPULAN}

Berdasarkan hasil wawancara yang telah dilakukan maka hasil dari penelitian ini adalah sebagai berikut :

Pelaksanaan pengelolaan dana desa di Kecamatan Sitinjau Laut yang menjadi objek penelitian telah terlaksana sesuai dengan aturan yang berlaku baik berdasarkan Peraturan Bupati maupun aturan lainnya yang sebagaimana mestinya. Sesuai dengan pengelolaan keuangan desa yang meliputi tahap mulai dari perencanaan, pelaksanaan, pelaporan, pertanggung jawaban, telah dilaksanakan di Kecamatan Sitinjau Laut dan semakin banyak Kecamatan-Kecamatan lainnya yang mampu patuh terhadap aturan pengelolaan dana desa tersebut. Dalam pelaksanaan pengelolaan dana desa ini telah sesuai dengan prosedur yang berlaku. Yang proses-proses pengelolaan dana desa dipergunakan untuk dapat memenuhi pengembangan ekonomi lokal yang potensial, dan pembangunan sarana dan prasarana desa.

\section{UCAPAN TERIMAKASIH}

Diucapkan terima kasih kepada semua pihak yang telah berkontribusi dalam penulisan jurnal ini, sehingga jurnal ini dapat diselesaikan dengan baik. Dan juga terima kasih kepada penglola jurnal Qawwam, sehingga bisa dipublikasan di OJS Qawwam. 


\section{DAFTAR PUSTAKA}

Anderson, James E.2010.Publik Policy Making. Holt, Rinehart and Winston : Michigan University

Pebi Julianto. 2014. Evaluasi Pelaksanaan Program Satu milyar Satu kecamatan (Samisake) di kecamatan Depati Tujuh Kabupaten Kerinci Provinsi jambi tahun 2014. OSF Preprints. Jakarta.

Arikunto, S. 2010. Prosedur Penelitian Suatu Pendekatan Praktik. Jakarta : Rineka Cipta

Agustino, Leo. 2012. Dasar-Dasar Kebijakan Publik. Bandung : Alfabeta

Pebi Julianto. 2020. Pengaruh Disiplin Kerja Terhadap Prestasi Kerja Pegawai pada Puskesmas di kecamatan Depati VII Kabupaten Kerinci. E Jurnal Administrasi Nusantara. Sungai Penuh.

Anggara, Sahya. 2014. Kebijakan Publik. Bandung : CV Pusataka Setia

Dunn, William N. 2003. Analisis Kebijakan Publik. Yogyakarta : Gadjah Mada University Press

Edi Suharto, 2008. Kebijakan Sosial Sebagai Kebijakan Publik. Bandung : Alfabeta

Marbun. 2007. Kamus Manajemen. Media Pustaka, Jakarata

Pebi Julianto. 2018. Pengaruh Sistem Kearsipan Terhadap Efisiensi Kerja Pada koantor Camat Air Hangat Kabupaten Kerinci. E Jurnal Administrasi Nusantara. Sungai Penuh.

Nurdin Usman, 2002, Konteks Implementasi Berbasis Kurikulum, Bandung, CV Sinar Baru

Riant Nugroho, 2004, Kebijakan Publik : Formulasi, Implementasi, Dan Evaluasi, Edisi Ke3, Jakarta : Elex Media Komputindo

Suyatna Uyat, 2009. Kebijakan Publik, Bandung : Kencana Utama

Pebi Julianto. 2018. Pengaruh Pengetahuan dan Keterampilan Terhadap Prestasi Kerja Pegawai Pada Mtsn Model Sungai Penuh. E Jurnal Administrasi Nusantara. Sungai Penuh.

Suharno, Edi 2010. Dasar-Dasar Kebijakan Publik. Yogyakarta : UNY Press

Sugiyono. 2011. Metode Penelitian Kuantitatif, Kualitatif Dan R\&D. Bandung : Remaja Rosdakarya

Samudra, Wibawa. 2004. Kebijakan Publik Proses Dan Analisis. Jakarta

Pebi Julianto. 2020. Implementasi Program Bantuan Pangan non Tunai (BPNT) di Kecamatan Sitinjau Laut Kabupaten Kerinci. E Jurnal Qawwam. Kerinci.

Thoha, M. 2012. Dimensi-Dimensi Prima Ilmu Administrasi Negara. Jakarta : Raja Grafindo Prasada

Winarno, Budi 2007. Kebijakan Publik : Teori Dan Proses. Yogyakarta ; Med Press

Undang-Undang No.6, Tahun 2014, Tentang Desa

Pebi Julianto. 2021. Pengaruh hard Skill dan Pelatihan Terhadap Kinerja Aparatur Sipil Negara Pada Kantor Camat Airn Hangat Kabupaten Kerinci. E Jurnal Administrasi Mahasiswa. Sungai Penuh.

Undang-Undang No.21, Tahun 2019, Tentang Dana Desa

Peraturan Bupati Kerinci No:21 Tahun 2019, Tentang Prioritas Penggunaan Dana Desa

Peraturan Menteri Keuangan Republik Indonesia No:205 Tahun 2019, Tentang Pengelolaan Dana Desa

Pebi Julianto. 2020. Partisipasi Masyarakat Dalam Program Bantuan Stimulan Perumahan Swadaya (BSPS) di Desa Koto Baru Kecamatan Koto baru (2020). E Jurnal Qawwam. Kerinci.

Peraturan Menteri Dalam Negeri No:113 Tahun 2014, Tentang Pengelolaan Keuangan Desa 
Peraturan Menteri Keuangan No:49 Tahun 2018, Tentang Standar Gaya Masukan Peraturan Menteri Dalam Negeri No:20 Tahun 2018, Tentang Penggunaan Dana Desa 